\title{
The impact of stock market development and inflation on economic growth in India: evidence using the ARDL bounds testing and VECM approaches
}

\author{
Rudra P. Pradhan* \\ Vinod Gupta School of Management, Indian Institute of Technology \\ Kharagpur, WB 721302, India \\ E-mail: rudrap@vgsom.iitkgp.ernet.in \\ *Corresponding author
}

\section{Flávio de São Pedro Filho}

Universidade Federal de Rondônia,

Campus José Ribeiro Filho,

BR 364, KM 9, 5, Via de Acesso para o Acre,

Porto Velho City, Estado de Rondônia, CEP 76800-000, Brazil

E-mail: flavio1954@gmail.com

\section{John H. Hall}

Department of Financial Management,

University of Pretoria,

Pretoria, Private Bag X20 Hatfield,

Pretoria 0028, Republic of South Africa

E-mail: john.hall@up.ac.za

\begin{abstract}
This paper investigates the impact of stock market development, money supply and inflation on economic growth in India during the post-globalisation era of the 1990s, especially during the period from 1994 to 2012. Using autoregressive distributive lag (ARDL) bounds testing approach, the study finds stock market development, money supply, inflation and economic growth are cointegrated, suggesting the presence of a long-run equilibrium relationship between them. The vector autoregressive error correction model (VECM) further confirms the existence of both bidirectional and unidirectional causality between economic growth, money supply, inflation and stock market development in India. The policy implication of this study is that inflation and money supply can be considered a policy variable to predict both economic growth and stock market development in the Indian economy during the post globalisation era.
\end{abstract}

Keywords: stock market; money supply economic growth; inflation; autoregressive distributive lag; ARDL; vector autoregressive error correction model; VECM; India. 
Reference to this paper should be made as follows: Pradhan, R.P., de São Pedro Filho, F. and Hall, J.H. (2014) 'The impact of stock market development and inflation on economic growth in India: evidence using the ARDL bounds testing and VECM approaches', Int. J. Economics and Business Research, Vol. 8, No. 2, pp.143-160.

Biographical notes: Rudra P. Pradhan is a SAP Fellow and Assistant Professor at Vinod Gupta School of Management, Indian Institute of Technology (IIT) Kharagpur, India. He received his $\mathrm{PhD}$ in Infrastructure Finance from IIT Kharagpur, India. He is a reviewer and board member of various journals such as African Journal of Political Science and International Relations (Associate Editor), Energy Systems, Review of Urban and Regional Development Studies, International Journal of Financial Research, Empirica, International Journal of Public Policy, etc. For his credit, he has a number of publications in many international journals. He is the editor of nine books in the area of infrastructure finance and financial markets. His specialisation is econometric modelling and infrastructure finance.

Flávio de São Pedro Filho is an Adjunct Professor and researcher at the Programme of Post Graduation in Administration (PPGMAD)/Foundation Federal University of Rondônia, Brazil. He holds a Doctor in Business Management from the Universidad Autónoma de Asunción, Paraguay, and Doctor in Administration from the Uniersidade de São Paulo, Brazil. He is a member at the European International Business Academy and member for Evaluation and Qualification of $\mathrm{PhD}$ Thesis at the Aligarh Muslim University in India and University of the Punjab in Pakistan. He is a referee at the Harvard University/Harvard Kennedy School of Government for the China Goes Global Conference. He is the editor, referee and advisory board member for various international scientific journals.

John H. Hall is a Professor in the Department of Financial Management at the University of Pretoria in the Republic of South Africa. He has published numerous articles in scholarly journals (some of which have received best paper awards) and has presented research papers on a number of conferences both locally and internationally. He has supervised a number of doctoral and Master's students.

\section{Introduction}

In this paper, we take a fresh look at the empirical evidence on the long-run relationship between stock market development (SMD), money supply, inflation and economic growth in India. This is done in order to examine the possible direction of causality between SMD, inflation and growth and to offer some policy suggestions about how these variables may be addressed in future to achieve faster financial development and higher economic growth.

We examine this problem from two angles. First, we attempt to establish whether and how SMD has contributed to economic growth in the Indian economy during the postglobalisation era of the 1990s and first decade of the 21st century. Second, we investigate whether inflation and money supply are the significant factors that affected the relationship between SMD and economic growth in the same period. Our two key objectives were to discover any long-run relationships relating to SMD, economic 
growth, money supply and inflation, and to ascertain the direction of any causality in respect of these relationships.

The methods used in pursuit of these two objectives were the autoregressive distributive lag (ARDL) bounds testing approach and the vector autoregressive error correction model (VECM).

The remainder of this paper consists of four more sections. Following on from the first section introduction, Section 2 sets out the theoretical framework. Section 3 describes the database and methods used in the study. Section 4 presents the results and a discussion of the findings. Section 5 provides a conclusion and comments on the potential policy implications of the findings.

\section{Theoretical framework}

This study is based on the theory of economic development proposed by Schumpeter (1911), and explores additional concepts to the treated object. Is this a holistic vision of interdependence in face of the changes that are emerging from the economic environment on various situations? This paper focuses on financial factors to explain their involvement in economic growth. This paper does so by testing for the cointegration of the variables, and the estimated coefficients in the short-term and the long-term, in order to understand the impact of SMD and inflation on economic growth.

It is widely agreed in contemporary economic literature that financial development tends to be positively associated with economic growth (Jude, 2010). Indeed, the relationship between financial development and economic growth has been the focus of both theoretical and empirical research since the seminal work of Schumpeter (1911) was published. Much of the evidence on the relationship between finance and growth is predicated on bank-based measures such as the broad money supply, domestic credit, private sector credit and financial reserves (Pradhan, 2012). However, the emphasis in the research has increasingly shifted to stock market indicators, mainly because of widespread SMD across the world, and its large-scale impact on economic growth. For instance, Arestis and Demetriades (1997) argue that financial development and economic growth influence each other positively in the process of development. They claim that the financial sector and real sectors interact with each other in all stages of development. That implies that at no stage is there a purely one-way relationship between financial development and economic growth.

It is important to undertake any investigation into causality with care, because both financial development and economic growth can be driven by some variables that they share, such as savings, investment, trade and interest rates. For instance, Rajan and Zingales (1998) contend that savings might affect the current level of financial development and future economic growth. A higher propensity to save leads the financial system to expand, and to the accumulation of more savings. Allocating these funds efficiently in turn fosters higher economic growth. Similarly, Courakis (1984) argues that financial deepening through additional deposits can only be realised by changing interest rates: low interest rates discourage savings, whereas high interest rates promote capital accumulation. Fry (1997) claims that higher interest rates discourage entrepreneurs from investing in low return projects, increasing the productivity of physical capital. It is common in the endogenous financial growth literature to use interest rates as a variable in 
the function of financial depth (for example, Chaiechi, 2012). A positive relationship between trade and economic growth is also well documented in the literature (Tekin, 2012), and there is new research showing that trade openness, finance and growth may be related (Gries et al., 2009).

Demirguc-Kunt and Levine (1996) investigated the relationship between SMD and financial intermediary development. They found that countries with better developed stock markets also have more developed financial intermediaries. They conclude that SMD goes hand-in-hand with financial intermediary development.

However, the expansion of financial systems may also be induced by economic growth; in other words, economic growth may create a demand for more financial services, and in turn the financial system will grow in response to economic expansion. As economic activities grow, there is a higher demand for both physical and liquid capital. Hence, growth in the real sector induces the financial sector to expand, thereby increasing competition between financial intermediaries and market efficiency (Berthelemy and Varoudakis, 1996). Importantly, the cost of financial services constitutes a significant fixed component, so that the average cost falls if the volume of transactions increases. Therefore, wealthier economies generate a greater demand for financial services, and are more able to afford a costly financial system. Since transaction volume is positively associated with the level of income, financial institutions such as banks and stock markets tend to emerge once a given critical level of income is reached. Empirical support for this proposition can be found in studies by Atje and Jovanovic (1993), and Demetriades and Hussein (1996).

It has been argued that well-developed stock markets may offer different kinds of financial services than the banking system, and may therefore provide a different kind of impetus to investment and growth than the development of the banking system (Cooray, 2010; Rousseau and Wachtel, 2000). For instance, increased stock market capitalisation (MAC), measured either by the ratio of the stock market value to the GDP, or by the number of listed companies, may improve an economy's ability to mobilise capital and diversify risk (Levine and Zervos, 1996). In the light of this argument, in recent years, the relationship between stock market growth and economic growth has received a considerable amount of attention from policymakers, economists and international investors.

It is against this backdrop that the current paper attempts to study the impact of SMD on economic growth in the Indian economy, with particular reference to the era of globalisation in the 1990s. Methodologically, two approaches can be used to examine the dynamic relationship between economic growth and the stock market - a cross-correlation approach and Granger's causality approach. The results of prior studies suggest that results based on the cross-correlation approach tend to be unique to the context in most studies (for example, Beck and Levine, 2004; Levine and Zervos, 1998), whereas the findings of studies based on causality tests tend to be controversial (for example, Hassan et al., 2011; Kar et al., 2011; Enisan and Olufisayo, 2009).

This study extends the empirical literature on the causal relation between SMD and economic growth. The main innovation in this paper is the use of a multivariate framework in which, in addition to economic growth and SMD, we incorporate inflation and money supply. This marries the Granger causality approach on the stock market-growth nexus with on the inflation-growth nexus and money supply-growth nexus. The inclusion of inflation and money supply in the SMD-economic growth nexus is highly relevant, as it highlights the issue of finance-growth stability in the economy. 
The second innovation of this paper is to investigate causality relating to SMD, economic growth, inflation and money supply in India, especially in the post-globalisation era following on from the 1990s. In India, globalisation in the 1990s involved wide and deep change. It was marked by a decided U-turn in the economic policy followed by India in the preceding 58 years of centralised economic planning (Pradhan, 2010; Sachs et al., 1991).

\section{Database and methods of study}

Monthly time series data from 1994 to 2012 for the Indian economy were employed. The data were obtained from the Handbook of Statistics on Indian Economy, issued by the Reserve Bank of India, Mumbai (RBI, 2012). Our sample covers periods characterised by tremendous economic growth and SMD in the Indian economy.

We used two distinct indicators of the stock market: $M A C$ and turnover ratio $(T U R)$. The $M A C$ was the product of share price and the number of shares outstanding for all stocks traded in India's stock exchanges and should reflect the importance of financing through equity issues in the capital mobilisation and resource allocation process (Rousseau and Xiao, 2007). The TUR was the value of the traders of domestic shares on domestic exchanges divided by the value of listed domestic shares. It was an efficiency indicator of the stock market as it measures the degree of activity of the stock market relative to its size (Cooray, 2010; Levine, 1999). Some models predict countries with illiquid markets will create disincentives to long run investments because it was comparatively difficult to sell one's stake in the firm. In contrast, more liquid stock markets reduce disincentives to long run investment, since liquid markets provide a ready exit-option for investors. This could boost more efficient resource allocation and faster economic growth (Cheng, 2012; Torre et al., 2007). The other indicators used in this study are broad money supply (MOS), inflation and economic growth. The MOS was the sum total of currency outside banks, demand deposits other than those of the central government, the time, savings, and foreign currency deposits of resident sectors other than the central government, bank and traveller's checks, and other securities such as certificates of deposit and commercial paper. In principle, a rising BMS may reflect more extensive use of currency rather than an increase in the volume of bank deposits. This may be common at an early stage of economic developments in which barter system of transactions are being replaced by market exchange. This is a more representative measure of banking sector development in particular and financial development in general (Wolde-Rufael, 2009; King and Levine, 1993). The inflation was calculated by using the wholesale price index (WPI), and economic growth was calculated by using the index of industrial production (IIP). The study tested the following hypotheses:

$\mathrm{H}_{1} \quad \mathrm{SMD}$ Granger-causes economic growth. This is termed the SMD-led growth hypothesis.

$\mathrm{H}_{2}$ Inflation (INF) Granger-causes economic growth. This is termed the INF-led growth hypothesis.

$\mathrm{H}_{3}$ SMD Granger-causes inflation. This is termed the SMD-led inflation hypothesis. 
$\mathrm{H}_{4}$ Money supply (SOM) Granger-causes economic growth. This is termed the SOM-led growth hypothesis.

$\mathrm{H}_{5}$ Money supply Granger-causes inflation. This is termed the SOM-led inflation hypothesis.

$\mathrm{H}_{6}$ Money supply Granger-causes SMD. This is termed the SOM-led SMD hypothesis.

In this study, the tests for the SMD-led growth hypothesis $\left(\mathrm{H}_{1}\right)$ and its counterparts (the INF-led growth hypothesis, $\mathrm{H}_{2}$; the SMD-led inflation hypothesis, $\mathrm{H}_{3}$; the SOM-led growth hypothesis, $\mathrm{H}_{4}$; $\mathrm{SOM}$-led inflation hypothesis, $\mathrm{H}_{5}$; and SOM-led SMD hypothesis, $\mathrm{H}_{6}$ ) were performed in two steps:

- Step 1 involved tests for cointegration

- Step 2 involved tests for Granger causality.

The ARDL bounds testing approach and VECM were employed for testing these three hypotheses $\left(\mathrm{H}_{1}, \mathrm{H}_{2}, \mathrm{H}_{3}, \mathrm{H}_{4}, \mathrm{H}_{5}\right.$, and $\left.\mathrm{H}_{6}\right)$.

This section provides a brief review of the methodologies adopted in this paper. We deployed the ARDL bounds testing approach developed by Pesaran and Pesaran (1997), and Pesaran et al. $(2000,2001)$, to identify the possible causal relationship between SMD, economic growth and inflation. The ARDL method involves two steps: first, testing the long-run equilibrium relationship between SMD, economic growth, money supply and inflation; second, estimating short- and long-run causalities. These two steps are briefly discussed below.

\section{Step 1 Testing cointegration}

The concept of cointegration, introduced by Granger (1988), is a multivariate problem that is very relevant to the issue of how to determine a long-run relationship between variables. A long-run relationship, from a statistical point of view, implies that variables move together over time so that short-term disturbances arising from the long-term trend are corrected. The basic concept underlying cointegration is simple: if the difference between two non-stationary series is itself stationary, then the two series are cointegrated. If two or more series are cointegrated, then the variables can be interpreted as being in a long-run equilibrium relationship. By contrast, a lack of cointegration suggests that such variables have no long-run equilibrium relationship, and in principle, they can diverge from each other arbitrarily (Dickey et al., 1991). When a collection of time-series observations becomes stationary only after first diverging, an individual time series may display linear combinations that are stationary without diverging. Such collections of series are usually called cointegrated (Granger, 1988) if integration of the first order is implied.

Following the above discussion, we employ cointegration analysis to establish whether a long-run relationship exists among the set of such possibly integrated variables. In such investigations, one can use a number of cointegration tests, such as the two-step approach developed by Engle and Granger (1987), the vector autoregressive (VAR) approach developed by Johansen (1988), or the ARDL bounds test approach developed by Pesaran and Pesaran (1997).

In this paper, we chose to employ the ARDL bounds testing framework to identify the existence of any long-run relationships between SMD, money supply, inflation and 
economic growth. This technique was chosen because this framework offers a number of advantages compared to other conventional methods such as Engle and Granger's (1987), and Johansen and Juselius's (1990) methods. For instance, these two conventional cointegration methods estimate long-run relationships in a context of a system of the equations, whereas the ARDL method uses only a single reduced form of equation (Pesaran and Shin, 1999).

Furthermore, the ARDL approach does not involve pre-testing variables. That means the test examines the long-run equilibrium relationship between variables, irrespective of whether the underlying regressors are purely I (0), I (1) or fractionally integrated (Pesaran et al., 2001; Bahmani-Oskooee and Ng, 2002). In this way, ARDL estimation avoids the problem of non-stationary time series data. This feature alone, given the characteristics of the cyclical components of the data, made the other standard cointegration techniques unsuitable. Even the use of existing unit root tests to identify the order of integration was highly questionable. The ARDL model eliminates the need to use the large number of specifications required in other standard cointegration tests. These include decisions regarding the inclusion of the number of variables (both explained and explanatory), the treatment of deterministic elements, the choice of lag lengths, etc. (Duasa, 2007).

The empirical results achieved in tests such as cointegration are generally very sensitive to the method chosen and the various alternative choices available in the estimation procedure (Pesaran and Smith, 1998). With the ARDL, it is possible for different variables to have different optimal lags, which is impossible using other standard cointegration tests. The ARDL model uses a sufficient number of lags to capture the data-generating process in a general-to-specific modelling framework (Laurenceson and Chai, 2003). Most importantly, the ARDL model can be used with limited sample data and can still provide robust results relating to the cointegration analysis (Narayan, 2005; Narayan and Smyth, 2005; Pesaran et al., 2000). In this section, we deployed the ARDL $[p, q, r, s, T]$ model below to determine the presence of long-run relationships between variables.

To test the presence of cointegration between SMD, economic growth, money supply and inflation, we used the following ARDL $[p, q, r, s, T]$ models:

$$
\begin{aligned}
& \Delta \ln m a c_{t}=\mu_{0 m a c}+\sum_{i=1}^{p} \lambda_{i m a c} \Delta \ln m a c_{t-i}+\sum_{j=1}^{q} \lambda_{j m a c} \Delta i i p_{t-j} \\
& +\sum_{k=1}^{r} \lambda_{k m a c} \Delta \ln w p i_{t-k}+\sum_{l=1}^{T} \lambda_{l m a c} \Delta m o s_{t-l} \\
& \delta_{1 \text { mac }} \ln m a c_{t-1}+\delta_{2 \text { mac }} \ln i i p_{t-1}+\delta_{3 \operatorname{mac}} \ln w p i_{t-1}+\delta_{4 m a c} \ln m o s_{t-1}+\zeta_{t} \\
& \Delta \ln t u r_{t}=\mu_{0 t u r}+\sum_{i=1}^{p} \lambda_{i t u r} \Delta \ln t u r_{t-i}+\sum_{j=1}^{q} \lambda_{j t u r} \Delta i i p_{t-j} \\
& +\sum_{k=1}^{r} \lambda_{k t u r} \Delta \ln w p i_{t-k}+\sum_{l=1}^{T} \lambda_{l t u r} \Delta \operatorname{mos}_{t-l} \\
& \delta_{1 \text { tur }} \ln t u r_{t-1}+\delta_{2 t u r} \ln i i p_{t-1}+\delta_{3 t u r} \ln w p i_{t-l}+\delta_{4 t u r} \ln m o s_{t-1}+\xi_{t}
\end{aligned}
$$


where

- $\Delta$ represents change

- $\quad \mu_{m a c}$ and $\mu_{t u r}$ are the drift components

- $\quad \zeta_{t}$ and $\xi_{t}$ are white noise

- $\quad \lambda$ is a short-run coefficient

- $\delta$ is the corresponding long-run multiplier of the underlying ARDL model.

The null hypothesis of 'no cointegration' for equation (1), is $\mathrm{H}_{0}: \delta_{1 \text { mac }}=\delta_{2 \text { mac }}=\delta_{3 \text { mac }}=$ $\delta_{4 m a c}=0$, compared to the alternative hypothesis of cointegration, $\mathrm{H}_{1}: \delta_{1 \text { mac }} \neq 0, \delta_{2 \text { mac }} \neq 0$, $\delta_{3 \text { mac }} \neq 0, \delta_{4 \text { mac }} \neq 0$. The null hypothesis of 'no cointegration', for equation (2), is $\mathrm{H}_{0}: \delta_{1 \text { tur }}=\delta_{2 \text { tur }}=\delta_{3 \text { tur }}=\delta_{4 \text { tur }}=0$, compared to the alternative hypothesis of cointegration $\mathrm{H}_{1}: \delta_{1 \text { tur }} \neq 0, \delta_{2 \text { tur }} \neq 0, \delta_{3 \text { tur }} \neq 0, \delta_{4 \text { tur }} \neq 0$. The null hypotheses are tested by using the general F-statistics and by comparing them with critical values set out by Pesaran et al. (2001), and Pesaran and Pesaran (1997).

The test involves asymptotic critical value bounds, depending on whether the variables are I (0) and/or I (1). Two sets of critical values are generated. One set refers to the I (1) series, and the other refers to the I (0) series. The critical values for the I (1) series are referred to as upper bound critical values; the critical values for the I (0) series are referred to as lower bound critical values (for more detail, see Pesaran and Smith, 1998). To determine the order of series, we employed Phillips and Perron's (1988) unit root test and augmented this with the Dickey Fuller test (Dickey and Fuller, 1981).

If the computed F-statistics were above the upper bound, the null hypothesis of cointegration had to be rejected, indicating evidence of a long-run equilibrium relationship between the variables, regardless of the order of integration of the variables. If the test statistic fell below the lower bound, we could not reject the null hypothesis of cointegration, indicating the absence of a long-run equilibrium relationship. If the test statistics fell between the bounds, a conclusive inference could not be made without knowing the order of integration of the underlying regressors.

\section{Step 2 Estimation of long-run and short-run coefficients}

This step involves the estimation of long- and short-run dynamics by using the following vector error correction model (VECM):

$$
\begin{aligned}
& \Delta m a c_{t}=\lambda_{0}+\sum_{j=1}^{p} \lambda_{1 m a c j} \Delta m a c_{t-j}+\sum_{j=1}^{q} \lambda_{2 m a c j} \Delta i i p_{t-j} \\
& +\sum_{j=1}^{r} \lambda_{3 m a c j} \Delta w p i_{t-j}+\sum_{j=1}^{T} \lambda_{4 m a c j} \Delta m o s_{t-j} \\
& \eta_{m a c} E C M_{t-1}+\zeta_{t} \\
& \Delta t u r_{t}=\lambda_{0}+\sum_{j=1}^{p} \lambda_{1 t u r j} \Delta t u r_{t-j}+\sum_{j=1}^{q} \lambda_{2 t u r j} \Delta i i p_{t-j}+\sum_{j=1}^{r} \lambda_{3 t u r j} \Delta w p i_{t-j}+\sum_{j=1}^{T} \lambda_{4 t u r j} \Delta m o o_{t-j} \\
& \eta_{t u r} E C M_{t-1}+\zeta_{t}
\end{aligned}
$$


where $\eta_{\text {mac }}$ and $\eta_{\text {tur }}$ are the speed of adjustment parameters and are expected to be negative. These parameters can indicate how quickly the current differences in the stock market respond to the error correction term disequilibrium in the previous period. The $E C M_{t-1}$ represents the lagged error term, which is estimated from the residuals of equations (1) and (2). The $E C M_{t-1}$ indicates the speed of the adjustment back to the long-run equilibrium after a short-run shock.

It can be noted that the estimations of both ARDL and VECM are very sensitive to lag length. We used both the Akaike information criterion (AIC) and the Bayesian information criterion (BIC) to choose the optimum lag length, as recommended by Burnham and Anderson (2004).

In addition, we conducted diagnostic and stability tests for the goodness-of-fit of the ARDL and VECM equations. The diagnostic tests examined the serial correlation by means of the Lagrange multiplier test of residual serial correlation (Durbin, 1970), the functional form by means of Ramsey's (1983) RESET test of square of the fitted values, normality by means of the Jarque-Bera test (Jarque and Bera, 1980, 1987) and heteroskedasticity based on the regression of squared residuals on squared fitted values (White, 1987; Harrison and McCabe, 1979). The structural stability was examined by means of the cumulative sum (CUSUM) and cumulative sum of squares (CUSUMSQ), as suggested by Brown et al. (1975). The CUSUM and CUSUMSQ statistics are updated recursively and plotted against the break points. If the plots of the CUSUM and CUSUMSQ statistics stay within the 5\% critical bound, the null hypothesis for all coefficients in the given regression is stable and cannot be rejected (Jalil and Feridun, 2011; Pattichis, 2001).

The data used in the present study were the index of industrial production (IIP) (as a proxy for economic growth), the BSE MAC and TUR (as a proxy for SMD), the WPI (as a proxy for inflation), and the broad money supply (M2). The data were monthly averages, covering the period from April 1994 to December 2012. The variables were obtained from the Handbook of Statistics on Indian Economy (RBI, 2012). The variables used in this study were in logarithmic form.

\section{Results and discussion}

The empirical results are reported in this section. Tables 1 and 2 report the descriptive statistics and correlation matrix of the variables respectively.

Table 1 Descriptive statistics

\begin{tabular}{lccccc} 
Variables & IIP & MAC & TUR & WPI & MOS \\
\hline Mean & 2.28 & 6.12 & 2.56 & 2.24 & 6.25 \\
Median & 2.25 & 5.90 & 2.65 & 2.24 & 6.25 \\
Std. deviation & 0.15 & 0.45 & 0.44 & 0.11 & 0.36 \\
Skewness & 0.24 & 0.41 & -0.82 & 0.02 & 0.06 \\
Kurtosis & 2.02 & 1.52 & 2.94 & 1.85 & 1.85
\end{tabular}

Notes: IIP: index of industrial production; MAC: market capitalisation; TUR: turnover ratio; WPI: wholesale price index; and MOS: broad money supply (M2). 
Table 2 Correlation matrix

\begin{tabular}{lccccc} 
Variables & IIP & MAC & TUR & WPI & MOS \\
\hline IIP & 1.00 & & & & \\
MAC & $0.88^{*}$ & 1.00 & & & \\
TUR & $0.82^{*}$ & $0.76^{*}$ & 1.00 & & \\
WPI & $0.88^{*}$ & $0.94^{*}$ & $0.80^{*}$ & 1.00 & \\
MOS & $0.89^{*}$ & $0.94^{*}$ & $0.80^{*}$ & $0.99^{*}$ & 1.00
\end{tabular}

Note: *Statistically significant at $1 \%$ probability level; and all the other notations are defined in Table 1.

The correlation results show a significant and positive association between economic growth and SMD, between economic growth and inflation, and between SMD and inflation.

Following the correlation results, we also report the unit root results for knowing the order of integration of the variables. This is essential for the validity of ARDL model. We deployed augmented Dickey Fuller (ADF; Dickey and Fuller, 1979) and Phillips and Perron (PP; Phillips and Perron, 1988) tests for the same. Table 3 reports the results of ADF and PP unit root tests.

Table 3 Results of unit root test (ADF and PP)

\begin{tabular}{|c|c|c|c|c|c|}
\hline \multirow[b]{2}{*}{ Variables } & \multicolumn{2}{|c|}{ ADF test } & \multicolumn{2}{|c|}{ PP test } & \multirow{2}{*}{$\begin{array}{c}\text { Decision at the firs } \\
\text { difference }\end{array}$} \\
\hline & Level & $\begin{array}{c}\text { First } \\
\text { difference }\end{array}$ & Level & $\begin{array}{c}\text { First } \\
\text { difference }\end{array}$ & \\
\hline \multicolumn{6}{|c|}{ Model 1: With no intercept and no trend } \\
\hline IIP & 0.89 & $-18.8^{*}$ & 0.49 & $-19.3^{*}$ & 1 (1): stationary \\
\hline TUR & 0.20 & $-16.7^{*}$ & 0.55 & $-17.4^{*}$ & 1 (1): stationary \\
\hline MAC & 2.26 & $-12.9^{*}$ & 2.11 & $-12.9^{*}$ & 1 (1): stationary \\
\hline WPI & 5.72 & $-6.76^{*}$ & 6.68 & $-10.1^{*}$ & 1 (1): stationary \\
\hline MOS & 2.67 & $-6.66^{*}$ & 2.27 & $-8.17^{*}$ & 1 (1): stationary \\
\hline \multicolumn{6}{|c|}{ Model 2: With intercept and no trend } \\
\hline IIP & -1.65 & $-18.5^{*}$ & -2.00 & $-19.3^{*}$ & 1 (1): stationary \\
\hline MAC & -0.33 & $-13.1 *$ & -0.40 & $-13.1^{*}$ & 1 (1): stationary \\
\hline TUR & -2.0 & $-13.1^{*}$ & -2.40 & $-17.7^{*}$ & 1 (1): stationary \\
\hline WPI & -0.41 & $-12.0^{*}$ & -0.45 & $-12.1^{*}$ & 1 (1): stationary \\
\hline MOS & 0.23 & $-12.9 *$ & 0.52 & $-15.3 *$ & 1 (1): stationary \\
\hline \multicolumn{6}{|c|}{ Model 3: With intercept and trend } \\
\hline IIP & -0.87 & $-18.9^{*}$ & -2.37 & $-19.2 *$ & 1 (1): stationary \\
\hline MAC & -1.89 & $-13.1 *$ & -2.04 & $-13.1^{*}$ & 1 (1): stationary \\
\hline TUR & -2.17 & $-16.7^{*}$ & -2.17 & $-18.1^{*}$ & 1 (1): stationary \\
\hline WPI & -1.14 & $-12.1 *$ & -2.58 & $-12.1^{*}$ & 1 (1): stationary \\
\hline MOS & -2.01 & $-12.9 *$ & -2.09 & $-15.3^{*}$ & 1 (1): stationary \\
\hline
\end{tabular}

Notes: ADF: augmented Dickey Fuller test; PP: Phillips-Perron test; IIP: index of industrial production; MAC: market capitalisation; TUR: turnover ratio; WPI: wholesale price index; MOS: broad money supply (M2); I (1): integration of order one; and *indicates statistical significance at $1 \%$ level. 
The tests results reflect that time series variables, namely mac, iip, wpi and mos, have unit roots in their levels. This is because the estimated ADF statistics cannot reject the null hypothesis of non-stationarity at the $5 \%$ level of significance. However, all variables are stationary at the $5 \%$ significance level of the first difference. Hence, the variables are I (1), that is they are integrated of order one. This reflects the possibility of cointegration between economic growth, SMD, inflation and money supply.

Table 4 Results of ARDL cointegration test

\begin{tabular}{|c|c|c|c|c|c|c|}
\hline Variables & \multicolumn{4}{|c|}{$F$-statistics } & \multicolumn{2}{|c|}{ Critical value } \\
\hline Model 1 & $M A C$ & $I I P$ & WPI & $M O S$ & & \\
\hline F-statistics & 2.79 & 1.88 & $17.1^{*}$ & $91.7^{*}$ & & \\
\hline Probability level c & nificanc & & & & $5 \%$ & $10 \%$ \\
\hline Upper bound & & & & & 3.95 & 3.24 \\
\hline Lower bound & & & & & 2.73 & 2.19 \\
\hline
\end{tabular}

Diagnostics tests

\begin{tabular}{lcccccc}
$\mathrm{R}^{2}$ & 0.99 & 0.95 & 0.99 & 0.99 & & \\
Adjusted R & 0.99 & 0.95 & 0.99 & 0.99 & & \\
F-statistics & 10,902 & 1,445 & 71,855 & 473,893 & & \\
\hline Model 2 & TUR & IIP & WPI & MOS & & \\
\hline F-statistics & 2.66 & 2.25 & $16.4^{*}$ & $91.3^{*}$ & $5 \%$ & $10 \%$ \\
Probability level of significance & & & & 3.95 & 3.24 \\
Upper bound & & & & & 2.73 & 2.19
\end{tabular}

Diagnostics tests

\begin{tabular}{|c|c|c|c|c|c|c|c|}
\hline $\mathrm{R}^{2}$ & 0.94 & 0.95 & 0.99 & 0.99 & & & \\
\hline Adjusted $\mathrm{R}^{2}$ & 0.94 & 0.95 & 0.99 & 0.99 & & & \\
\hline F-statistics & 1,125 & 1,474 & 71,803 & 472,247 & & & \\
\hline Model 3 & $M A C$ & $T U R$ & IIP & WPI & $M O S$ & & \\
\hline F-statistics & 2.62 & 1.73 & 1.85 & $13.6^{*}$ & $73.1^{*}$ & & \\
\hline \multicolumn{6}{|c|}{ Probability level of significance } & $5 \%$ & $10 \%$ \\
\hline \multicolumn{6}{|l|}{ Upper bound } & 3.95 & 3.24 \\
\hline \multicolumn{6}{|l|}{ Lower bound } & 2.73 & 2.19 \\
\hline
\end{tabular}

Diagnostics tests

$\begin{array}{lccccc}\mathrm{R}^{2} & 0.99 & 0.95 & 0.99 & 0.99 & 0.99 \\ \text { Adjusted R } & 0.99 & 0.95 & 0.99 & 0.99 & 0.99 \\ \text { F-statistics } & 7,692 & 783 & 1,102 & 53,914 & 353,806\end{array}$

Notes: IIP: index of industrial production; MAC: market capitalisation; TUR: turnover ratio; WPI: wholesale price index; MOS: broad money supply (M2); and *indicates statistical significance at a $1 \%$ level.

Source: Pesaran et al. (2001), and Pesaran and Pesaran (1997) 
The ARDL model was deployed for the same purpose. The results of the ARDL estimation are described in two parts: evidence of a long-run relationship (cointegration) and direction of causality (causation). For this purpose, we estimated equations (1) and (2) through the OLS procedure and computed the F-statistics for the joint significance of the lagged levels of variables to compare the results to the critical values provided by Pesaran et al. (2001). For equations (1) and (2), for Model 1 and Model 2, represented in equations (1) and (2), respectively, the calculated F-statistics - FWPI (WPI/MAC, IIP, MOS $)=17.1$ and FWPI $($ WPI/TUR, IIP, MOS $)=16.4-$ are higher than the upper bound critical value of 3.24 , at a $1 \%$ level of significance. Hence, the null hypothesis of 'no cointegration' cannot be accepted for the stock market ARDL model, where WPI is the dependent variable, and IIP, MOS and MAC/TUR are the independent variables.

Similarly, the null hypothesis of 'no cointegration' was rejected in the ARDL model when MOS was the dependent variable and IIP, WPI and MAC/TUR were the independent variables (see Table 4). The overall results indicate that there is evidence of a long-run equilibrium relationship between the variables, where WPI and MOS are the dependent variables. For robustness check, we also verified the test through Johansen and Juselius's (1990) cointegration test. The result shows one cointegrating vector among IIP, MOS, MAC, TUR and WPI. (The results are not made available here, due to space constraints.) In respect of the individual impact of independent variables on the dependent variable, the ARDL approach results indicate that MAC is the only variable that affects the TUR (and vice versa) significantly. The impact of the other variables was not as significant as those of the MAC and TUR (see Table 4).

To complement this study, the test of parameter stability (Porter and Kashyap, 1984) was employed, that is through the cumulative sum (CUSUM) and cumulative sum of squares (CUSUMSQ) (Brown et al., 1975). The CUSUM test uses the cumulative sum of recursive residuals based on the first $n$ observations and is updated recursively and plotted against the break point. The CUSUMSQ uses the squared recursive residuals and follows the same procedure. This means that CUSUM tests can be used even if the structural break point is unknown. If the plots of the CUSUM and CUSUMQ stay in the $5 \%$ critical bound, then the null hypothesis that all coefficients are stable cannot be rejected. Moreover, if either of the parallel lines is crossed, then the null hypothesis of parameter stability must be rejected at a 5\% level of significance. The results reveal that both the CUSUM and CUSUMSQ plots lie within the 5\% critical bound; hence, they show that the parameters of the model do not suffer from any structural instability over the period under review. (We do not include these figures, because of space constraints.)

Once we had the required information about the existence of cointegration (a long-run relationship), we proceeded to a multivariate Granger causality test, based on the VECM platform. Table 5 shows the multivariate Granger causalities between economic growth, SMD, inflation and money supply. The results indicate that the error correction term is not significant for all cases except for WPI as a dependent variable. The significance of the error correction term confirms the existence of long-run relationship between the variables, as determined earlier by the ARDL method. This suggests that economic growth, SMD, inflation and money supply can lead to adjustments in each other when there are any deviations from the long-run relationship. Moreover, the significance of error correction term with a negative sign shows that the established long-run relationship is stable (see also Bannerjee et al., 1998). 
The model also passes all diagnostic tests for the normality of the error term, serial correlation, autoregressive conditional heteroskedasticity, White's general test for heteroskedasticity and model specification (for more details, see Table 5).

Table 5 Results of VECM Causality

\begin{tabular}{|c|c|c|c|c|c|c|c|}
\hline \multirow{2}{*}{$\begin{array}{l}\text { Dependent } \\
\text { variables }\end{array}$} & \multicolumn{6}{|c|}{ Independent variables } & \multirow{2}{*}{ Inferences } \\
\hline & $\triangle M A C$ & $\triangle I I P$ & $\triangle T U R$ & $\triangle W P I$ & $\triangle M O S$ & $E C T t_{-1}$ & \\
\hline \multicolumn{8}{|c|}{ Model 1: MAC, IIP, WPI, MOS } \\
\hline$\triangle \mathrm{MAC}$ & ------ & $1.76^{* *}$ & & 0.25 & 0.23 & $-2.27 *$ & $\mathrm{IIP}=>\mathrm{MAC}$ \\
\hline$\Delta \mathrm{IIP}$ & $2.94 * *$ & ------ & & $1.83 * *$ & $8.02 *$ & $-2.31^{*}$ & $\begin{array}{c}\mathrm{MAC}=>\mathrm{IIP} ; \mathrm{WPI}=> \\
\mathrm{IIP} ; \mathrm{MOS}=>\text { IIP }\end{array}$ \\
\hline$\Delta \mathrm{WPI}$ & $4.88^{*}$ & 1.01 & & ------ & 0.57 & -0.77 & $\mathrm{MAC}=>$ WPI \\
\hline$\Delta \mathrm{MOS}$ & 1.10 & $2.16^{* *}$ & & $1.84 * *$ & ------ & $-1.69 * *$ & $\begin{array}{c}\mathrm{IIP}=>\text { MOS; } \mathrm{WPI}=> \\
\mathrm{MOS}\end{array}$ \\
\hline \multicolumn{8}{|c|}{ Model 2 TUR, IIP, WPI, MOS } \\
\hline$\Delta \mathrm{TUR}$ & & $1.98 * *$ & ------ & $1.82 * *$ & $3.50 *$ & $-3.72 *$ & $\begin{array}{l}\text { IIP => TUR; WPI => } \\
\text { TUR; MOS = > TUR }\end{array}$ \\
\hline$\Delta \mathrm{IIP}$ & & ------ & 1.52 & 1.58 & $6.91 *$ & $-2.77 *$ & MOS $=>$ IIP \\
\hline$\Delta \mathrm{WPI}$ & & 1.19 & $2.62 * *$ & ----- & 0.61 & -1.56 & TUR $=>$ WPI \\
\hline$\triangle \mathrm{MOS}$ & & $2.11 * * *$ & $3.82 *$ & $2.07 * * *$ & ------ & $-1.92 * *$ & $\begin{array}{c}\mathrm{IIP}=>\text { MOS; TUR }=> \\
\text { MOS; WPI = > MOS }\end{array}$ \\
\hline \multicolumn{8}{|c|}{ Model 3: MAC, TUR, IIP, WPI, MOS } \\
\hline$\Delta \mathrm{IIP}$ & $4.56^{*}$ & ------ & $3.15^{*}$ & 1.20 & $7.56^{*}$ & $-2.82^{*}$ & $\begin{array}{c}\text { MAC }=>\text { IIP; TUR }=> \\
\text { IIP; MOS = > IIP }\end{array}$ \\
\hline$\triangle \mathrm{MAC}$ & ------ & 0.97 & 0.05 & 0.40 & 0.20 & $-2.43 * *$ & \\
\hline$\Delta \mathrm{TUR}$ & $24.1 *$ & 1.36 & ------ & $1.72 * *$ & $3.61 *$ & $-3.05^{*}$ & $\begin{array}{c}\text { MAC }=>\text { TUR; WPI => } \\
\text { TUR; } \text { MOS = > TUR }\end{array}$ \\
\hline$\Delta \mathrm{WPI}$ & $3.32 *$ & 0.86 & 0.24 & ------ & 0.51 & -1.20 & $\mathrm{MAC}=>$ WPI \\
\hline$\triangle \mathrm{MOS}$ & 0.07 & $2.33 * *$ & $3.19 *$ & $1.86^{* *}$ & ------ & $-1.85^{* *}$ & $\begin{array}{l}\mathrm{IIP}=>\text { MOS; TUR=> } \\
\text { MOS; WPI => MOS }\end{array}$ \\
\hline
\end{tabular}

Notes: IIP: index of industrial production; MAC: market capitalisation; TUR: turnover ratio; WPI: wholesale price index; MOS: broad money supply (M2); ECT: error correction term; *indicates statistical significance at a $5 \%$ level; and **indicates statistical significance at a $10 \%$ level.

In respect of the short-run dynamics (the direction of causality), in Models 1 and 2, we found evidence of bidirectional causality between economic growth and SMD (IIP $<=>$ MAC; IIP $<=>$ TUR), bidirectional causality between money supply and economic growth (IIP $<=>$ MOS; IIP $<=>$ MOS) and unidirectional causality from SMD to inflation $(\mathrm{MAC}=>\mathrm{WPI})$, unidirectional causality form inflation to money supply (WPI $=>$ MOS) and unidirectional causality from inflation to economic growth (WPI => IIP). However, in Model 3, where we used all four variables simultaneously, we found bidirectional causality between money supply and economic growth (MOS $<=>$ IIP) and between SMD and money supply (TUR $<=>$ MOS). Besides, we found unidirectional causality from inflation to money supply (WPI $=>$ MOS), inflation to SMD (WPI $=>$ TUR), from SMD to economic growth $(\mathrm{MAC}=>$ IIP; TUR $=>$ IIP) and from SMD to 
inflation (MAC $=>$ WPI). Moreover, we found unidirectional causality MAC to TUR (MAC $=>$ TUR) (see Table 6).

Table 6 Long-run and short-run analysis

\begin{tabular}{lccccc} 
Dependent variables & IIP & MAC & TUR & WPI & MOS \\
\hline Long-run results & & & & & \\
IIP & & 1.36 & 1.19 & -0.58 & 1.15 \\
MAC & 0.57 & & 0.48 & 0.72 & 0.96 \\
TUR & $1.97^{* *}$ & -0.75 & & -1.12 & 0.20 \\
WPI & $1.90^{* *}$ & -1.72 & -0.95 & & $2.72^{* *}$ \\
MOS & -1.42 & $1.99^{* *}$ & 0.632 & $4.11^{*}$ & \\
Short-run results & & & & & \\
IIP & & 1.50 & 1.13 & -0.76 & $1.98^{* *}$ \\
MAC & 0.56 & & $5.80^{*}$ & 1.12 & 0.88 \\
TUR & $2.09^{* *}$ & $5.80^{*}$ & & -1.04 & 0.19 \\
WPI & $2.24^{* *}$ & $-2.11^{* *}$ & -0.84 & & 1.03 \\
MOS & $-1.66^{* *}$ & $2.17^{* *}$ & 0.586 & 1.10 & \\
ECT & $-2.83^{*}-1$ & $-2.13^{* *}$ & $-3.04^{*}$ & -1.20 & -1.49 \\
Diagnostic tests & & & & & \\
$\chi_{\text {normal }}^{2}$ & 11,687 & 17.4 & 15.85 & 14,021 & 96.08 \\
$\chi_{\text {serial }}^{2}$ & 12.69 & 0.22 & 11.37 & 7.606 & 0.415 \\
$\chi_{\text {arch }}^{2}$ & 5.508 & 1.30 & 15.66 & 3.364 & 0.034 \\
$\chi_{\text {remsay }}^{2}$ & 2.261 & 0.17 & 0.690 & 17.22 & 0.080
\end{tabular}

Notes: IIP: index of industrial production; MAC: market capitalisation; TUR: turnover ratio; WPI: wholesale price index; MOS: broad money supply (M2); ECT: error correction term; *indicates statistical significance at a $5 \%$ level; and **indicates statistical significance at a $10 \%$ level.

To complement this study, we use generalised impulse response functions (GIRFs). The GIRFs trace the effect of a one-time shock to one of the innovations on the current and future values of endogenous variables. The generalised impulse responses provided some insight into how shocks to a particular variable (such as IIP) can be affected by other variables (such as WPI, MOS and MAC/TUR). The GIRFs provided support for the presence of causality between these variables in the multivariate VAR system. (We do not include the details here because of space constraints; but the figures are available on request.)

\section{Conclusions and policy implications}

This paper examines the impacts of SMD and inflation on economic growth in India during the post globalisation era of 1990s, particularly for the period 1994 to 2012. The long-run relationships between these variables are intriguing and of acute interest to 
policy makers. Using the ARDL bounds testing approach of cointegration, suggested by Pesaran et al. (2001), together with VECM, the study reaches the following conclusions.

The ARDL cointegration results showed that SMD and inflation are cointegrated with economic growth, indicating the presence of a long-run equilibrium relationship between them. The VECM results showed that the error correction term is significant for SMD, money supply and economic growth, confirming the existence of a long-run relationship between them. With regard to the direction of causation, the study found evidence of unidirectional causality from MAC to TUR, unidirectional causality from SMD to economic growth (both MAC and the TUR), unidirectional causality from inflation to TUR, unidirectional causality from inflation to money supply and unidirectional causality from MAC to inflation. It also found the bidirectional causality between money supply and economic growth and between TUR and money supply.

A policy implication of this study is that inflation and money supply can be considered the best policy variable to predict economic growth and SMD in India during the era of globalisation of the 1990s. If policy-makers want to maintain sustainable economic growth and economic stability, they must focus on the stable money supply and keeping inflation in the economy mild in the long-term. Such a policy could be also supported by financial sector restructuring, especially in the stock market, in line, for instance, with the suggestions of Khan et al. (2005).

\section{References}

Arestis, P. and Demetriades, P. (1997) 'Financial development and economic growth: assessing the evidence', Economic Journal, Vol. 107, No. 442, pp.783-799.

Atje, R. and Jovanovic, B. (1993) 'Stock markets and developments', European Economic Review, Vol. 37, Nos. 2-3, pp.632-640.

Bahmani-Oskooee, M. and Ng, R.C.W. (2002) 'Long run demand for money in Hong Kong: an application of the ARDL model', International Journal of Business and Economics, Vol. 1, No. 2, pp.147-155.

Bannerjee, A., Dolado, J. and Mestre, R. (1998) 'Error correction mechanism tests for cointegration in single equation framework', Journal of Time Series Analysis, Vol. 19, No. 3, pp.267-283.

Beck, T. and Levine, R. (2004) 'Stock markets, banks, and growth: panel evidence', Journal of Banking and Finance, Vol. 28, No. 3, pp.423-442.

Berthelemy, J. and Varoudakis, A. (1996) 'Economic growth, convergence clubs, and the role of financial development', Oxford Economic Papers, Vol. 48, No. 2, pp.300-328.

Brown, R.L., Durbin, J. and Evans, J.M. (1975) 'Techniques for testing the consistency of regression relations over time', Journal of Royal Statistical Society, Vol. 37, No. 2, pp.149-192.

Burnham, K.P. and Anderson, D.R. (2004) 'Multimodal inference: understanding AIC and BIC in model selection', Sociological Methods and Research, Vol. 33, No. 2, pp.261-304.

Chaiechi, T. (2012) 'Financial development shocks and contemporaneous feedback effect on key macroeconomic indicators: a post Keynesian time series analysis', Economic Modelling, Vol. 29, No. 2, pp.487-501.

Cheng, S. (2012) 'Substitution or complementary effects between banking and stock markets: evidence from financial openness in Taiwan', Journal of International Financial Markets, Institutions and Money, Vol. 22, No. 3, pp.508-520.

Cooray, A. (2010) 'Do stock markets lead to economic growth?', Journal of Policy Modelling, Vol. 32, No. 4, pp.448-460. 
Courakis, A.S. (1984) 'Constraints on bank choices and financial repression in less developed countries', Oxford Bulletin of Economics and Statistics, Vol. 46, No. 4, pp.341-370.

Demetriades, P. and Hussein, K. (1996) 'Financial development and economic growth: cointegration and causality tests for 16 countries', Journal of Development Economics, Vol. 51, No. 2, pp.387-411.

Demirguc-Kunt, A. and Levine, R. (1996) 'Stock markets, corporate finance and economic growth: an overview', World Bank Economic Review, Vol. 10, No. 2, pp.223-239.

Dickey, D.A. and Fuller, W.A. (1979) 'Distribution of the estimators for autoregressive time series with a unit root', Journal of the American Statistical Association, Vol. 74, No. 366, pp.1057-1072.

Dickey, D.A. and Fuller, W.A. (1981) 'Likelihood ratio statistics for autoregressive time series with a unit root', Econometrica, Vol. 49, No. 4, pp.1057-1072.

Dickey, D.A., Jansen, D.W. and Fuller, W.A. (1991) 'A primer on cointegration with an application to money and income', Review Federal Reserve Bank of St. Louis, Vol. 73, No. 2, pp.58-78.

Duasa, J. (2007) 'Determinants of Malaysian trade balance: an ARDL bounds testing approach', Global Economic Review, Vol. 36, No. 1, pp.89-102.

Durbin, J. (1970) 'Testing for serial correlation in least squares regression when some of the regressors are lagged dependent variables', Econometrica, Vol. 38, No. 3, pp.410-421.

Engle, R.F. and Granger, C.W.J. (1987) 'Cointegration and error correction: representation, estimation and testing', Econometrica, Vol. 55, No. 2, pp.251-276.

Enisan, A.A. and Olufisayo, A.O. (2009) 'Stock market development and economic growth: evidence from seven Sub-Saharan African countries', Journal of Economics and Business, Vol. 61, No. 2, pp.162-171.

Fry, M.J. (1997) 'In favour of financial liberalization', Economic Journal, Vol. 107, No. 442, pp.754-770.

Granger, C.W.J. (1988) 'Some recent developments in a concept of causality', Journal of Econometrics, Vol. 39, Nos. 1-2, pp.199-211.

Gries, T., Kraft, M. and Meierrieks, D. (2009) 'Linkages between financial deepening, trade openness, and economic development: causality evidence from Sub-Saharan Africa', World Development, Vol. 37, No. 7, pp.1849-1860.

Harrison, M.J. and McCabe, B.P.M. (1979) 'A test for heteroscedasticity based on ordinary least squares residuals', Journal of the American Statistical Association, Vol. 74, No. 366, pp.494-499.

Hassanm, M.K., Sanchez, B. and Yu, J. (2011) 'Financial development and economic growth: new evidence from panel data', Quarterly Review of Economics and Finance, Vol. 51, No. 1, pp. $88-104$.

Hausman, J.A. (1978) 'Specification tests in econometrics', Econometrica, Vol. 46, pp.1251-1272.

Jalil, A. and Feridun, M. (2011) 'The impact of growth, energy and financial development on the environment in China: a cointegration analysis', Energy Economics, Vol. 33, No. 2, pp.284-291.

Jarque, C.J. and Bera, A.K. (1980) 'Efficient tests for normality, homoscedasticity and serial independence of regression residuals', Economics Letters, Vol. 6, No. 3, pp.255-259.

Jarque, C.J. and Bera, A.K. (1987) 'A test for normality of observations and regression residuals', International Statistical Review, Vol. 55, No. 2, pp.163-172.

Johansen, S. (1988) 'Statistical analysis of cointegrating vectors', Journal of Economics Dynamic and Control, Vol. 12, No. 2, pp.231-254.

Johansen, S. and Juselius, K. (1990) 'Maximum likelihood estimation and inference on cointegration with application to the demand for money', Oxford Bulletin of Economics and Statistics, Vol. 52, No. 2, pp.169-210.

Jude, E.C. (2010) 'Finance development and growth: a panel smooth regression approach', Journal of Economic Development, Vol. 35, No. 4, pp.15-33. 
Kar, M., Nazlioglu, S. and Agir, H. (2011) 'Financial development and economic growth nexus in the MENA countries: bootstrap panel Granger causality analysis', Economic Modelling, Vol. 28, Nos. 1-2, pp.685-693.

Khan, M.A., Qayyum, A. and Sheikh, S.A. (2005) 'Financial development and economic growth: the case of Pakistan', Pakistan Development Review, Vol. 44, No. 4, pp.819-837.

King, R. and Levine, R. (1993) 'Finance and growth: Schumpeter might be right', The Quarterly Journal of Economics, Vol. 108, No. 3, pp.717-737.

Laurenceson, J. and Chai, J.C.H. (2003) Financial Reform and Economic Development in China, Edward Elgar, Cheltenham, UK.

Levine, R. (1999) 'Law, finance and economic growth', Journal of Financial Intermediation, Vol. 8, Nos. 1-2, pp.8-35.

Levine, R. and Zervos, S. (1996) 'Stock market development and long-run growth', World Bank Economic Review, Vol. 10, No. 2, pp.323-339.

Levine, R. and Zervos, S. (1998) 'Stock markets, banks and economic growth', American Economic Review, Vol. 88, No. 3, pp.537-558.

Narayan, P.K. (2005) 'The relationship between saving and investment for Japan', Japan and the World Economy, Vol. 17, No. 3, pp.293-309.

Narayan, P.K. and Smyth, R. (2005) 'Trade liberalization and economic growth in Fiji: an empirical assessment using the ARDL approach', Journal of the Asia Pacific Economy, Vol. 10, No. 1, pp.96-115.

Pattichis, C. (2001) 'Trade, growth, and monetary union', Journal of Post Keynesian Economics, Vol. 24, No. 1, pp.125-147.

Pesaran, M.H. and Pesaran, B. (1997) Working with Microfit 4.0: Interactive Econometric Analysis, Oxford University Press, Oxford, UK.

Pesaran, M.H. and Shin, Y. (1999) 'An autoregressive distributive lag modelling approach to cointegration analysis', in Strom, S. (Ed.): Econometrics and Economic Theory in 20th Century: the Ragnar Frisch Centennial Symposium, pp.371-413, Cambridge University Press, Cambridge, UK.

Pesaran, M.H. and Smith, R. (1998) 'Structural analysis of cointegration VRS', Journal of Economic Surveys, Vol. 12, No. 5, pp.471-505.

Pesaran, M.H., Shin, Y. and Smith, R. (2000) 'Structural analysis of vector error correction models with Exogenous I (1) variables', Journal of Econometrics, Vol. 97, No. 2, pp.293-343.

Pesaran, M.H., Shin, Y. and Smith, R. (2001) 'Bounds testing approaches to the analysis of level relationships', Journal of Applied Econometrics, Vol. 16, No. 3, pp.289-326.

Phillips, P.C.B. and Perron, P. (1988) 'Testing for a unit root in time series regression', Biometrica, Vol. 75, No. 2, pp.335-346.

Porter, R.D. and Kashyap, A.K. (1984) 'Autocorrelation and the sensitivity of RESET', Economics Letters, Vol. 14, Nos. 2-3, pp.229-233.

Pradhan, R.P. (2010) 'Globalization in India: with special reference to 1990s', Journal of Economics and International Finance, Vol. 2, No. 5, pp.76-84.

Pradhan, R.P. (2012) 'Financial development and economic growth in selected Asian countries', in Pradhan, R.P. (Ed.): Project Financing, Bloomsbury Publishing, New Delhi, India.

Rajan, R. and Zingales, L. (1998) 'Financial dependence and growth', American Economic Review, Vol. 88, No. 3, pp.559-586.

Ramsey, J.B. (1983) 'Comment on diagnostic tests as residual analysis', Econometric Reviews, Vol. 2, No. 2, pp.241-224.

Reserve Bank of India (RBI) (2012) Handbook of Statistics on Indian Economy, Reserve Bank of India, Mumbai.

Rousseau, P. and Wachtel, P. (2000) 'Equity markets and growth: cross country evidence on timing and outcomes, 1980-1995', Journal of Banking and Finance, Vol. 24, No. 12, pp.1933-1957. 
Rousseau, P.L. and Xiao, S. (2007) 'Equity markets and growth: cross country evidence on timing and outcomes, 1980-1995', Journal of Banking and Finance, Vol. 24, No. 1, pp.1933-1957.

Sachs, J.D., Varshney, A. and Bajpai, N. (1991) India in the Era of Economic Reforms, Oxford University Press, New Delhi, India.

Schumpeter, J.A. (1911) The Theory of Economic Development, Harvard University Press, Cambridge, MA.

Tekin, R.B. (2012) 'Development aid, openness to trade and economic growth in least developed countries: bootstrap panel Granger causality analysis', Procedia, 4-6 May, Vol. 62, pp.716-721.

Torre, A., Gozzi, J.C. and Schmukler, S.L. (2007) 'Stock market development under globalization: whither the gains from reforms', Journal of Banking and Finance, Vol. 31, No. 12, pp.1731-1754.

White, H. (1987) 'Specification tests in dynamic models', in Bewley, T. (Ed.): Advances in Econometrics-Fifth World Congress, Vol. 1, pp.1-58, Cambridge University Press, New York.

Wolde-Rufael, Y. (2009) 'Re-examining thee financial development and economic growth nexus in Kenya', Economic Modelling, Vol. 26, No. 6, pp.1140-1146. 